\title{
Questioning the proverb 'more haste, less speed': Classic versus metabarcoding approaches for the diet study of a remote island endemic gecko
}

\author{
Vanessa Gil $^{\text {Equal first author, } 1}$, Catarina Jesus Pinho ${ }^{\text {Equal first author, } 2,3}$, Carlos Aguiar ${ }^{1}$, Carolina Jardim ${ }^{4}$, Rui Rebelo ${ }^{\text {Corresp., } 1}$, \\ Raquel Vasconcelos ${ }^{\text {Corresp. } 2}$ \\ ${ }^{1}$ Centre for Ecology, Evolution and Environmental Changes, Faculdade de Ciências da Universidade de Lisboa, Lisboa, Portugal \\ 2 CIBIO, Centro de Investigação em Biodiversidade e Recursos Genéticos, InBIO Laboratório Associado, Universidade do Porto, Vairão, Portugal \\ 3 Departamento de Biologia, Faculdade de Ciências da Universidade do Porto, Porto, Portugal \\ 4 Instituto das Florestas e Conservação da Natureza IP-RAM, Funchal, Madeira, Portugal \\ Corresponding Authors: Rui Rebelo, Raquel Vasconcelos \\ Email address: rmrebelo@fc.ul.pt, raquel.vasconcelos@cibio.up.pt
}

Dietary studies can reveal valuable information on how species exploit their habitats and are of particular importance for insular endemics conservation as these species present higher risk of extinction. Reptiles are often neglected in island systems, principally the ones inhabiting remote areas, therefore little is known on their ecological networks. The Selvagens gecko Tarentola (boettgeri) bischoffi, endemic to the remote and integral reserve of Selvagens Archipelago, is classified as Vulnerable by the Portuguese Red Data Book. Little is known about this gecko's ecology and dietary habits, but it is assumed to be exclusively insectivorous. The diet of the continental Tarentola species was already studied using classical methods. Only two studies have used next-generation sequencing (NGS) techniques for this genus thus far, and very few NGS studies have been employed for reptiles in general. Considering the lack of information on its diet and the conservation interest of the Selvagens gecko, we used morphological and DNA metabarcoding approaches to characterize its diet. The traditional method of morphological identification of prey remains in faecal pellets collected over a longer period was compared with metabarcoding of samples collected during rapid surveys. Molecular results revealed that this species is a generalist, feeding on invertebrate, plant and vertebrate items, whereas the morphological approaches were unable to detect the latter two. These results opened up new questions on the ecological role of the Selvagens gecko that deserves to be further explored, such as the possible predation on seabirds, plant services or trophic competition with the sympatric Madeira lizard Teira dugesii. Metabarcoding identified a greater diversity of dietary items at higher taxonomic resolution, but morphological identification enabled calculation of relative abundances and biomasses of ingested arthropods, and detected a dietary shift on invertebrate preys between seasons. Results of this study
Peerr reviewing PDFT(2019:04:36364:2:1: NEW 18 Oct 2019) 
highlight the global applicability of rapid metabarcoding surveys for understudied taxa on remote islands that are difficult to access. We recommend using the metabarcoding approach, even if 'speedy' sampling only is possible, but we must highlight that disregarding long-term ecological data may lead to 'hasty' conclusion. 


\section{Questioning the proverb 'more haste, less speed'. Classic versus metabarcoding approaches for the diet study of a remote island endemic gecko}

Vanessa Gil Equal first author, 1 , Catarina Jesus Pinho Equal first author, 2, 3 , Carlos Aguiar ${ }^{1}$, Carolina Jardim 4 , Rui Rebelo Corresp., 1, Raquel Vasconcelos Corresp. 2

${ }^{1}$ Centre for Ecology, Evolution and Environmental Changes, Faculdade de Ciências da Universidade de Lisboa, Lisboa, Portugal

${ }^{2}$ CIBIO, Centro de Investigação em Biodiversidade e Recursos Genéticos, InBIO Laboratório Associado, Universidade do Porto, Vairão, Portugal

${ }^{3}$ Departamento de Biologia, Faculdade de Ciências da Universidade do Porto, Porto, Portugal

${ }^{4}$ Instituto das Florestas e Conservação da Natureza IP-RAM, Funchal, Madeira, Portugal

Corresponding Authors: Rui Rebelo, Raquel Vasconcelos

Email address: rmrebelo@fc.ul.pt, raquel.vasconcelos@cibio.up.pt 


\section{Abstract}

2 Dietary studies can reveal valuable information on how species exploit their habitats and are of 3 particular importance for insular endemics conservation as these species present higher risk of 4 extinction. Reptiles are often neglected in island systems, principally the ones inhabiting remote 5 areas, therefore little is known on their ecological networks. The Selvagens gecko Tarentola 6 (boettgeri) bischoffi, endemic to the remote and integral reserve of Selvagens Archipelago, is 7 classified as Vulnerable by the Portuguese Red Data Book. Little is known about this gecko's 8 ecology and dietary habits, but it is assumed to be exclusively insectivorous. The diet of the 9 continental Tarentola species was already studied using classical methods. Only two studies have used next-generation sequencing (NGS) techniques for this genus thus far, and very few NGS studies have been employed for reptiles in general. Considering the lack of information on its diet and the conservation interest of the Selvagens gecko, we used morphological and DNA metabarcoding approaches to characterize its diet. The traditional method of morphological identification of prey remains in faecal pellets collected over a longer period was compared with metabarcoding of samples collected during rapid surveys. Molecular results revealed that this species is a generalist, feeding on invertebrate, plant and vertebrate items, whereas the morphological approaches were unable to detect the latter two. These results opened up new questions on the ecological role of the Selvagens gecko that deserves to be further explored, such as the possible predation on seabirds, plant services or trophic competition with the sympatric Madeira lizard Teira dugesii. Metabarcoding identified a greater diversity of dietary items at higher taxonomic resolution, but morphological identification enabled calculation of relative abundances and biomasses of ingested arthropods, and detected a dietary shift on invertebrate preys between seasons. Results of this study highlight the global applicability of rapid metabarcoding surveys for understudied taxa on remote islands that are difficult to access. We recommend using the metabarcoding approach, even if 'speedy' sampling only is possible, but we must highlight that disregarding long-term ecological data may lead to 'hasty' conclusions.

\section{Introduction}

An island is usually considered a natural laboratory due to its geographical nature and to the presence of its uniquely evolved biota (Whittaker et al., 2017). Even though islands generally present a small number of species in relation to mainland systems, high numbers of endemics are known to occur, especially on remote islands (Whittaker \& Fernández-Palacios, 2007). These endemic species are more prone to extinction due to the synergy of genetic and demographic factors (Frankham, 1997). Insular systems represent simplified models, ideal for studying ecological networks, as the species inhabit more confined areas which allows more thorough sampling. Studies on such systems are of great importance to ensure accuracy when developing conservation measures (Caujapé-Castells et al., 2010; Frankham, 1997). Comprehending the feeding habits of a species increases the knowledge about the way it exploits its environment. 
38

39

40

41

42

43

44

45

46

47

48

49

50

51

52

53

54

55

56

57

58

59

60

61

62

63

64

65

66

67

68

69

70

71

72

73

74

75

76

77

Therefore, dietary studies represent an important topic in conservation. These are essential for gaining insight on species to which information remains scarce (Pérez-Mellado et al., 2011) and contributing to existing studies on the subject (e.g.: Neves et al., 2017). An interesting example are insular reptiles, which often vastly differ in their diets when compared to continental congeners (Brock, Donihue \& Pafilis, 2014; Sagonas et al., 2015). Some studies show a generalization of diet in island species (Sagonas et al., 2015), while others reveal drastic changes in the trophic niche as a result of the need to adapt to their different insular prey availability (Briggs et al., 2012; Carretero \& Lo Cascio, 2010).

Geckos comprise the largest lizard family, with about 2000 species worldwide (inhabiting mainly warm climate regions), and include several iconic examples of island colonization across the three main oceans (Vitt \& Caldwell, 2013). Within this family, the genus Tarentola is the most widespread in the Western Mediterranean and presents us with several island endemics in Macaronesia (Rato, Carranza \& Harris, 2012; Vasconcelos, Carranza \& James Harris, 2010). Several studies based on morphological identification of prey were performed on the diet of the most widespread species, such as Tarentola annularis (Geoffroy-St-Hilaire, 1827) and Tarentola mauritanica (Linnaeus, 1758). In northern Egypt, the former's diet mainly consists of flying arthropods with some vestiges of plant material (Ibrahim, 2004); however, predation on small mammals has also been reported (Crochet \& Renoult, 2008). According to the latest studies specific to the Iberian Peninsula, T. mauritanica dietary habits consist almost exclusively of ground-dwelling arthropods (Gil, Guerrero \& Perez-Mellado, 1994; Hódar \& Pleguezuelos, 1999; Hódar et al., 2006), contrasting with the patterns found in Rome, Italy, which show mostly flying arthropods, such as Diptera and adult Lepidoptera (Capula \& Luiselli, 1994).

Few studies have been performed using next-generation sequencing (NGS) techniques to assess the diet of reptiles, and only two to the best of our knowledge on Tarentola geckos (Pinho et al., 2018; Seguro, 2017). DNA metabarcoding is a non-invasive technique that allows the identification of multiple food items in a species diet through sequencing of standardized DNA fragments (Pompanon et al., 2012). Highly variable DNA regions that enable species-level identification are amplified using universal or group-specific primers which bind to conserved sites across multiple taxa. Metabarcoding is extremely advantageous when studying species dietary habits as it enables the gathering of large datasets from remote areas without requiring the time or effort needed by conventional tools. Compared to traditional methods, metabarcoding maximizes resolution as well as detection of soft, small and inconspicuous prey items, and it is less reliant on taxonomic expertise; ultimately, its use can correct biases in ecological models (Pompanon et al., 2012). In spite of the potential of this approach, it is important to know that there are also methodological implications. One of these being that it only provides species presences and not their proportions in samples (Piñol et al., 2015). The number of reads does not represent the abundance of prey due to differences in prey digestibility (Jarman et al., 2013) and potential biases during PCR amplification (Pompanon et al., 2012). Additionally, the obtained 
91

92

93

94

95

96

97

98

99

100

101

102

103

104

105

106

107

108

109

110

111

112

113

114 data can be biased during DNA extraction, PCR pooling, sequencing and bioinformatic processing (Pompanon et al., 2012). Nevertheless, as metabarcoding continues to evolve at an accelerated rate, these and other issues are gradually tackled.

The Selvagens gecko, Tarentola (boettgeri) bischoffi (Joger, 1984), is endemic to the remote Selvagens Archipelago (Fig. 1), located about $250 \mathrm{~km}$ south of Madeira Island (Oliveira et al., 2005). It occurs in three isolated subpopulations, which correspond to the three largest islands of the archipelago (Rebelo, 2008) (Fig. 1), and is considered Vulnerable by the Portuguese Red Data Book (Oliveira et al., 2005). The closest relatives of this gecko live in two islands of the Canary Archipelago - Gran Canaria, Tarentola boettgeri boettgeri (Steindachner, 1891), and El Hierro, Tarentola boettgeri hierrensis (Joger \& Bischoff 1983). The group is related to Tarentola mauritanica populations from North Africa, from which it separated about 17.5 million years ago as a result of an ancient Macaronesian colonization (Carranza et al., 2000).

Previous studies inferred that Selvagens gecko voluntarily eats insects and avoids rotten fruits (Olivera et al., 2010), but studies focused on its feeding habits are still lacking. Considering the poor availability of information on Selvagens gecko diet and its plasticity, we used two approaches in this study to characterize the diet of this endemic species for the first time. We compared the traditional method of morphological identification of prey remains in faecal pellets collected over a longer period of time with metabarcoding of samples collected during rapid surveys. Additionally, we built a reference collection (DNA and morphological), so we could have more robust taxa identification and deduce on food availability between seasons. The results of this study highlight the global applicability of rapid metabarcoding surveys for understudied taxa on remote islands with difficult access.

\section{Materials \& Methods}

\section{Study area}

Sampling was carried out on the largest island of the archipelago, Selvagem Grande (Fig. 1), a plateau approx. $120 \mathrm{~m}$ a.s.l. which is surrounded by steep cliffs. The climate is characteristically semi-arid, as its low altitude does not favour precipitation (below $200 \mathrm{~mm}$ ). However, occasional winter torrential floods may occur.

The flora of Selvagens Islands is composed of approximately 75 taxa, seven being exclusively endemics. The majority are considered threatened (Sim-Sim et al., 2014). Since the successful eradication of house mouse Mus musculus and European rabbit Oryctolagus cuniculus in 2005 
115 (Olivera et al., 2010), the scarce but steadily recovering vegetation in the plateau is now mainly 116 composed of shrubby sea-blite Suaeda vera Forssk. ex J. F. Gmel with some individuals of the

117 Macaronesian endemic Schizogyne sericea (L.f.) DC. (Penado et al., 2015).

118

119

120

121

122

123

124

125

126

127

128

129

130

131

132

133

134

135

136

137

138

139

140

141

142

143

144

145

146

147

148

149

150

151

152

153

154

The Selvagens Archipelago, which was classified as an Important Bird Area (IBA) by Birdlife International (BirdLife International, 2019), is one of the most important breeding areas for seabirds in Macaronesia. Nine breeding species occur, and the archipelago plays a key role in the protection of Cory's shearwater Calonectris borealis (Cory, 1881) by sheltering one of the largest breeding colonies in the world (Granadeiro et al., 2006). There are also two endemic reptiles - the mainly diurnal Madeira lizard Teira dugesii (Milne-Edwards, 1829) and the strictly nocturnal Selvagens gecko Tarentola (boettgeri) bischoffi, our study species. Despite having segregated activity periods, some cases of predation of Madeira lizard on eggs of Selvagens gecko have been reported (Oliveira et al., 2005; Rebelo, 2008). The terrestrial arthropod community on the Island is diverse, including 201 taxa (Borges et al., 2008a).

\section{Sampling}

Diet studies reliant on prey identification from faecal samples represent only a snapshot of the last ingested meal. Considering that diet composition can differ with prey availability, which fluctuates with seasonal variations, sampling must be conducted over several periods of time to ensure a thorough description of species diet. Taking that into account, two periods were sampled with our classical approach to check if there were differences in Selvagens gecko diet due to season. Sampling took place in intermittent years at the end of summer (6th -15 th September 2010 and 10th - 11th September 2017) and in late spring (9th - 30th May 2011).

Gecko faecal pellets ( $N=16$ in September 2010, $N=66$ in May 2011, and $N=27$ in September 2017) were obtained by gently pressing the abdomen of adult individuals ( $>45 \mathrm{~mm} \mathrm{SVL}$; Penado et al, 2015) which were caught by lifting rocks on the plateau during the day. In 2017 , and for the metabarcoding analyses, pellets were stored in tubes with $96 \%$ ethanol for DNA preservation, and labelled with the respective code of the animal.

The soil arthropod community was sampled with $50 \mathrm{~mL}$ pitfall traps, which were left open for 12 hours on two occasions per season in 2010/2011 and on one occasion in 2017. To obtain a reference collection of the island's arthropods for morphological identification, five traps containing water, $70 \%$ alcohol and detergent were placed in each of four 1 ha squares at evenly spaced intervals along the island plateau, and left open overnight, in 2010 and 2011. In September 2017, eight traps were placed on two areas of the island for the DNA reference collection of arthropods. These pitfall traps did not contain detergent to prevent DNA degradation. All arthropods were photographed and identified to the family level whenever possible. Specimens collected in 2010 and 2011 were also weighted to obtain an estimate of the

PeerJ reviewing PDF | (2019:04:36364:2:1:NEW 18 Oct 2019) 
155

156

157

158

159

160

161

162

163

164

165

166

167

168

169

170

171

172

173

174

175

176

177

178

179

180

181

182

183

184

185

186

187

188

189

190

191

192

193

194

average body mass of each taxonomic category. A leg or wing sample was used from the specimens collected in 2017 of each different Operational Taxonomic Unit (OTU) identified by the experts (C. Aguiar; R. Rebelo) to perform DNA extraction. Plant and vertebrate samples (pieces of leafs and dead animals) were also collected in 2017 to build the DNA reference collection, except those already present on GenBank.

The work within the Natural Reserve of Selvagem Grande was carried out with the permission of Parque Natural da Madeira, PNM (Permits in 2010 and 2011, and License nr 09/IFCN/2017). Sampling and protocols were approved by PNM.

\section{Morphological analysis}

In 2010 and 2011 pellets were stored dry in plastic tubes, and later dispersed in water and examined with a binocular magnifying glass. The numbers of each prey item in each pellet were estimated from the cephalic capsules, wings (including elytra) and legs, following the criterion of the minimum number (e.g.: six formicid legs would count as one individual ant). Prey items were identified to the lowest possible taxonomic level.

Metabarcoding analysis

Arthropod DNA from the reference collection was extracted using saline extraction methods (Carranza et al., 1999) and amplified using a modified version of the IN16STK-1F/IN16STK-1R primers (Tables S1, S2 and S3) targeting the mitochondrial 16S rRNA gene (Kartzinel \& Pringle, 2015) to match with diet sequences. The standard COI barcode fragment was amplified using LCO1490/HC02198 primers following PCR conditions described in Folmer et al. (1994). The amplification and sequencing of the latter marker allowed confirmation of dubious taxonomic assignations by comparison with sequences available in the BOLD database (http://boldsystems.org/).

Vertebrate samples from the reference collection were extracted using saline methods and amplified for the V5-loop fragment of the mitochondrial $12 \mathrm{~S}$ gene using $12 \mathrm{sv} 5 \mathrm{~F}$ and $12 \mathrm{Ssv} 5 \mathrm{R}$ primers (Riaz et al., 2011; Tables S1, S2 and S3).

Plants were photographed and identified by experts (M.M. Romeiras), and DNA extracted using DNeasy Plant Mini Kit (Qiagen, Crawley, UK) following some alterations according to Romeiras et al. (2015), and amplified using primer 'e' and ' $\mathrm{f}$ ' (Taberlet et al., 1991) targeting the chloroplast trnL (UAA) intron (Tables $S 1, S 2$ and $S 3$ ). DNA from all reference samples was sequenced using Sanger sequencing (310 Applied Biosystem DNA Sequencing Apparatus). Chromatograms were checked manually to detect and correct sequencing errors. 
195

196

197

198

199

200

201

202

203

204

205

206

207

208

209

210

211

212

213

214

215

216

217

218

219

220

221

222

223

224

225

226

227

228

229

230

231

232

233

The collected pellets were completely dehydrated in an incubator at $50^{\circ} \mathrm{C}$ in order to remove all traces of ethanol. Then, DNA was extracted using the Stool DNA Isolation Kit (Norgen Biotek Corp.Canada), following the manufacturer's instructions. Three different DNA fragments were chosen to identify the distinct prey groups presumably preyed by the study species. For plants, the $\mathrm{g} / \mathrm{h}$ primers that target the short P6-loop of chloroplast trnL (UAA) intron were used (Taberlet et al., 2007). For invertebrates and vertebrates, the same IN16STK-1F/IN16STK-1R and $12 \mathrm{sv} 5 \mathrm{~F} / 12 \mathrm{Ssv} 5 \mathrm{R}$ primers, respectively, were used as described above. To avoid the amplification of $T$. (boettgeri) bischoffi DNA, a blocking primer (5 '-

CTCCTCTAGGTTGGTTTGGGACACCGTC (C3 spacer) -3') was designed, according to previous references by Vestheim \& Jarman (2008).

We further modified all primers used for metabarcoding in order to contain Illumina adaptors and a 5-bp individual identification barcode to allow individual identification of each sample.

Succeeding amplification of both pellets and reference collection, library preparation was carried out following the Illumina MiSeq 16S Metagenomic Sequencing Library Preparation protocol (Illumina, 2013) (see Pinho et al., 2018 for details). Samples were pooled per fragment at equimolar concentrations $(15 \mathrm{nM})$. The final pool comprising the three fragments was quantified by qPCR (KAPA Library Quant Kit qPCR Mix, Bio-Rad ThiCycler), diluted to $4 \mathrm{nM}$, and run on a MiSeq sequencer (Illumina) using a 2 x 150 bp MiSeq Reagent Kit for an expected average of 12,000 paired-end reads per sample.

The sequences were processed using the software package Obitools (https://git.metabarcoding.org/obitools/obitools; see Pinho et al., 2018 for details), using the command illuminapairedend for aligning sequences with quality over 40, the command ngsfilter to assign reads to samples and primers and remove barcodes, and the command obiclean to collapse reads into unique haplotypes. Samples with less than 100 reads and haplotypes representing less than $1 \%$ of the total number were excluded. Taxa were assigned by comparing the obtained sequences against GenBank online database using BLAST (Basic Local Alignment Search Tool; https://www.ncbi.nlm.nih.gov/), and lists of species occurring on Selvagens Islands (Borges et al., 2008b; Table S4). Sequences with less than 90\% BLAST identity were assigned to class level. Sequences with 90-95\% BLAST identity were assigned to the family level.

Remaining sequences with 95\% BLAST identity or higher were assigned to species or genus level (Table S5). Prey items were identified to the lowest possible taxonomic level (Table S5).

\section{Methods and seasons comparisons}


234 Accumulation curves were built for all three sampling moments considering family level 235 assignments.

236

237

238

239

240

241

242

243

244

245

246

247

248

249

250

251

252

253

254

255

256

257

258

259

260

261

262

263

264

265

266

267

268

269

270

The Shannon-Wiener Diversity Index was calculated to characterize the gecko's diet in the 2010 and 2011 samples and the diversity indices were compared between seasons with t-tests (Zar, 2010). This approach was not used for the 2017 samples as it is not possible to estimate the number of individuals belonging to each prey species using metabarcoding (see discussion).

Diet composition was expressed in terms of frequency of occurrence (\% FO) for both methods, and as numerical frequency $(\% \mathrm{~N})$ and percentage of biomass $(\% \mathrm{~B})$ for the morphological identification only. As the main prey items identified were adult holometabolous insects (see results), for the estimation of the ingested biomass we used the average weight of the exemplars collected in the pitfalls. A relative importance index (RII) was assigned to each taxonomic category from the above metrics as $\mathrm{RII}=\% \mathrm{FO} *(\% \mathrm{~N}+\% \mathrm{~B})$ (Pinkas, 1971). This calculus was possible only for those species for which we had biomass estimates. All the calculations were performed with Microsoft Excel (2007).

\section{Results}

\section{Reference collection}

A total of twelve, ten and eleven arthropod families were identified in the samples collected in the pitfalls in September 2010, May 2011 and September 2017, respectively. Four of the invertebrates represent new sequences in GenBank (XXXX; Table S4). The abundance or presence of each type of arthropod in each of the three sampling occasions is shown in Table 1. Ants (Formicidae) were the most numerous, with similar abundance in both seasons. All the other families were relatively rare, with the exceptions of Psyllipsocidae in September and a single species of Diptera in May. In 2017, we collected nine plant species and two species of vertebrates for the DNA library (Table 1). We provide 10 new sequences of plants and two of vertebrates known to occur on Selvagens before this study (XXXX; Table S4).

\section{Gecko's diet}

Diet composition in each of the two seasons and for both methods is expressed in Table 2 and Fig. 2. Using classical methods, a total of 324 specimens from seven orders and 16 different arthropod families were retrieved and identified from the pellets (11 families in September 2010 
271 and 10 families in May 2011). Ants (mainly the common species Monomorium subopacum

272 Smith, 1858) were the most numerous prey in both seasons (Table 2 and Fig. 2); however, their 273 frequency and relative importance index were strikingly lower in May than in September. This

274 shift was due to higher consumption of the much heavier carabids (mainly the common species

275 Hegeter latebricola Wollaston, 1854) in spring. Other beetle species were also more frequently 276 consumed in May, as well as Diptera (Table 2 and Fig. 2). Ants were the most frequent prey in 277 September, having been found in $81.25 \%$ of the pellets, whereas in May the most frequent prey 278 was Carabidae (39.4\% of the pellets). Prey diversity in the pellets was higher in May than in 279 September (H'09/10 =0.84; H 05/11 = 1.90; $\left.\mathrm{t}_{188}=-8,192 ; \mathrm{P}<0.0001\right)$. Considering the 280 percentage of biomass, Carabidae was the most important in both seasons, as the biomass of a 281 single carabid is roughly 500 times that of an ant (as a single carabid weighs roughly $56 \mathrm{mg}$ and 282 ants weight $0.11 \mathrm{mg}$ on average). The higher values of the relative importance index belong to 283 Formicidae in September and to Carabidae in May. No plants or vertebrate OTUs were retrieved 284 from pellets using the classical method (Table 2).

285

286

287

288

289

290

291

292

293

294

295

296

297

298

299

300

301

302

303

304

305

306

307

308

With metabarcoding, after bioinformatic filtering, a coverage of about 5000 sequence reads per sample was obtained. Results revealed invertebrate and plant items presenting almost the same proportion in the samples ( $77.7 \%$ and $74.1 \%$ FO, respectively). Vertebrates were also detected in $33 \%$ of the samples. With this method, a total of 106 diet items, 62 corresponding to arthropods - 19 of them new records for Selvagens, 37 to plants -11 of them new records - and seven to vertebrates were identified ( $95.1 \%$ of sequence reads were assigned taxonomically). For arthropods a total of 12 orders and 29 families were identified. For plants, we were able to identify 16 orders and 21 families, and six orders and six families for vertebrates. The plant family Plumbaginaceae (specifically Limonium papillatum Webb \& Berthel, 1891) had the highest frequency of occurrence of the group, and one of the greatest together with nonidentified Lepidoptera in the general diet considering all taxonomic groups. For the arthropods, even though non-identified Lepidoptera were more frequent, Culicidae was the arthropod family with a higher incidence in the samples. Regarding vertebrates, Procellariidae (specifically Calonectris borealis) was the family with a higher frequency of occurrence. Other vertebrates were also found in the diet with lower frequencies, such as fishes and reptiles (detected in only one sample).

Taxa accumulation curves using the results of the classic method (Fig. 3) very quickly reached a plateau (after five pellets in both seasons), indicating that even the reduced September sampling effort is probably enough to characterize the species diet. However, using metabarcoding we did not reach that plateau (Fig. 3).

PeerJ reviewing PDF | (2019:04:36364:2:1:NEW 18 Oct 2019) 
309

310

311

312

313

314

315

316

317

318

319

320

321

322

323

324

325

326

327

328

329

330

331

332

333

334

335

336

337

338

339

340

341

342

343

344

345

346

\section{Discussion}

Our results represent the first data on the dietary habits in nature of the endemic and threatened T. (boettgeri) bischoffi. Looking exclusively into the morphological results, we have concluded that the Selvagens gecko appears to be mostly myrmecophagous at the end of the dry season, shifting to larger prey (especially carabids) during spring. In fact, ants were consistently the most numerous prey in both seasons. The much heavier beetles, which provided the highest biomass, were also consumed in both seasons. In May, although Formicidae continued to dominate the diet of the species, its occurrence was much lower than in September, with an increase of Carabidae, Diptera and other Coleoptera.

Proportion wise, the difference in ant availability between the two seasons was almost nonexistent. Therefore, a higher consumption of beetles in May is not explained by a variation in ant availability. The selection of more nutritious prey by the geckos could explain this rise. The increase in consumption of non-ant arthropods, such as Carabidae (which were also the most frequent), some other Coleoptera and Diptera from September to May, coincided with the decrease in ant consumption. Since Carabidae was also the most important prey in terms of biomass in both seasons and presented the higher values for the relative importance index in May, the species seems to show a dietary pattern similar to that described by Hódar \& Pleguezuelos (1999) for T. mauritanica. Hódar \& Pleguezuelos (1999) showed that between April and July, Lepidoptera and Carabidae larvae and Araneae were the main groups consumed by $T$. mauritanica, whereas from July to September their presence in the diet decreased with an increase in Homoptera, Coleoptera and Formicidae. This pattern is related to the preference for less sclerotized, highly profitable groups such as larvae in spring and a shift to prey species adapted to drought and food scarcity in summer.

Although evidence exists, it was not possible to prove that the differences in the consumption of prey were due to variations in the food supply. On the other hand, the higher consumption of non-ant arthropods in May coincided with a longer rainy season in the previous months, which agrees with Greenville \& Dickman (2005), who showed that flexibility of feeding strategies can be expected in arid environments with a large variation in precipitation. James (1991), in his study regarding Ctenotus species in Australia, observed that the proportion of termites in the diet was higher during drier periods, concluding that termites constitute a good source of food during droughts. The Selvagens gecko seems to be a seasonal ant specialist since this item has always been the most consumed; a possible increase in the availability of other prey will lead to the adoption of a more varied diet, and therefore a more generalist food regime. This supports the theory that many reptiles maintain a flexible diet by opportunistically exploiting diverse food resources when available (Murray \& Dickman, 1994). 
347 By adding the metabarcoding results, a different picture emerges: 13 more families of arthropods 348 were recovered comparatively to when using classical methods. Even though the collection of

349

350

351

352

353

354

355

356

357

358

359

360

361

362

363

364

365

366

367

368

369

370

371

372

373

374

375

376

377

378

379

380

381

382

383

384

385

386 pellet samples for the morphological analysis was conducted during a longer period - sampled during two seasons for approximately three weeks in total, as opposed to only one day of sampling in September 2017 - we were able to retrieve more information (16 versus 29 arthropod families). In general, classical diet methods tend to underestimate the frequency of occurrence of prey with parts that are totally digested (Brown, Jarman \& Symondson, 2012), such as some soft-bodied arthropods as Zygentoma and Lepidoptera, which were only detected by using DNA-based methods. Classical methods also tend to more easily detect hard-bodied groups such as Coleoptera.

It is important to note that metabarcoding methodologies still do not provide quantitative data on the biomass of prey consumed, rendering impossible to detect of diet shifts such as the ones identified with the morphological analysis. The number of reads of a determined DNA sequence could reflect the amount of food ingested, yet this does not always happen (Acinas et al., 2005; Polz \& Cavanaugh, 1998). This issue is related primarily to biological factors, such as the inevitable differences in the number of DNA copies for unit of mass of the ingested prey, or the differential degradation of DNA during digestion, depending on the type of prey (Pompanon $e t$ al., 2012). Also, the number of reads can be influenced by technical factors during PCR amplification when the target DNA is exponentially amplified, which is why an accurate marker choice is so important. Additionally, bias can also occur during the extraction of DNA (MartinLaurent et al., 2001), DNA pooling and sequencing since there is a preference for the amplification of smaller sequences (Porazinska et al., 2010), and during bioinformatic processing (Amend, Seifert \& Bruns, 2010). This represents a disadvantage in relation to classic methods which provide more accurate information on the relative abundance of a specific item in the diet, and thus the quantitative importance of certain prey species.

Metabarcoding results revealed that Selvagens gecko does not rely exclusively on arthropods and probably has a more generalist diet, consuming also plant and vertebrate items. This information is important considering the current Vulnerable status of the gecko. Moreover, plants seem to be as important as arthropods in the diet, occurring roughly in the same proportions. Soft and nutrient-rich plant parts, such as nectar, pollen and some fruits are not identifiable in pellets using classic methods as these became imperceptible after the passage through the digestive tract. The small size of this gecko (average snout-vent length circa $6 \mathrm{~cm}$ ) may prevent ingestion of large seeds or harder plant parts, which may explain the lack of plant material detected using morphological identification of Selvagens gecko pellets. Even though other classic studies detected plants in reptile diets (Ibrahim, 2004; Pietruszka et al., 1986; Rodríguez et al., 2008), those focused on much larger species (Tarentola annularis, Gerrhosaurus skoogi, and Gallotia galloti, respectively) with higher bite force and gape size. In addition, the study of Ibrahim (2004) was based on stomach contents, such as the study of Sadek (1981) on T. dugesii. 
387 Therefore, plant parts were probably not completely digested allowing easier detection.

388

389

390

391

392

393

394

395

396

397

398

399

400

401

402

403

404

405

406

407

408

409

410

411

412

413

414

415

416

417

418

419

420

421

422

423

424

425

426

Assessing stomach contents ofan endemic and threatened species was neither possible nor desirable.

Although metabarcoding detected plants in most pellets, it could be the case that plant DNA might have been detected due to the consumption of phytophagous arthropods. However, given that at least six pellets with plants and no invertebrates were found, we conclude that plants are in fact a primary food item for these geckos. In particular, the species Limonium papillatum, though being rare in the island, appears to be an important diet item. This plant possibly provides some nutritious advantage, such as rich pollen. A similar pattern was observed for another Tarentola endemic from Cabo Verde (Pinho et al., 2018).

Due to the low number of terrestrial predators, it is common for insular reptile species to become diet generalists as they can reach high densities and face higher competition for food (PérezMellado \& Corti, 1993). Moreover, the low arthropod availability in these arid systems may force reptiles to expand their dietary range and even become top predators (Miranda, 2017). In this way, an increase in the consumption of plants by island reptiles is usually detected, such as in several Podarcis species of the Mediterranean islands (Pérez-Mellado \& Corti, 1993). On islands, reptiles may even play a significant role in seed dispersal and pollination as the number of pollinators is low. This includes some geckos, such as the diurnal Phelsumas and the nocturnal Hoplodactylus (Godínez-Álvarez, 2004). This also might be the case for Selvagens gecko.

Island reptiles may even prey on seabirds, ingesting their eggs or juveniles, or simply their regurgitations, a behaviour observed in other Tarentola species (Alcover \& McMinn, 1994; Mateo et al., 2016; Schleich, 1984; Lopes et al., 2019) and also in the sympatric T. dugesii (Matias et al., 2009). In fact, even with the small sampling effort of the metabarcoding approach, it was possible to detect a link between the Selvagens gecko and seven vertebrate OTUs not detected with the classical methods. On the other hand, the single detection of a turtle as a diet item can be a case of secondary predation, by ingestion of faeces of some flying predator that preyed dead turtles elsewhere, or their predators, such as ants that preyed on their remains. As we showed with metabarcoding that our study species is somehow linked to Cory's Shearwater Calonectris borealis, it would be important to study how the gecko interacts with this bird. However, we could not infer the type of trophic relation of this gecko with seabirds. This could vary from predation to commensalism, in this case through secondary ingestion of bird feathers or faeces while scavenging bird regurgitations (as we detected fish DNA in the gecko's diet). This link could even be due to secondary consumption when feeding on ants, as studies have shown that they can feed extensively on seabirds (Boieiro et al., 2018; Plentovich, Russell \& Fejeran, 2018). After considering all evidence we have discarded this last possibility since pellets with confirmed seabird sequences are different from those with confirmed ant sequences.

PeerJ reviewing PDF | (2019:04:36364:2:1:NEW 18 Oct 2019) 
427 Similarly, we could not distinguish if the low frequency of DNA of other seabirds in the diet of 428 this gecko is related to the inaccessibility of their nests, to the consumption of degraded DNA 429 from their faeces, or both. In addition, it was not possible to detect potential cases of cannibalism 430 mentioned in other works with Tarentola (Mateo et al., 2016), due to the amplification of 431 Selvagens gecko DNA having been prevented by the use of a blocking primer.

432

433

434

435

436

437

438

439

440

441

442

443

444

445

446

447

448

449

450

451

452

453

454

455

456

457

458

459

460

461

462

463

464

465

466

Despite the limitations described above, the metabarcoding approach allowed the detection of a much wider range of diet items (56 considering all three groups) and a more accurate taxonomic description of those items than classic methods (e.g. Diptera was only identifiable to the order level with the latter but at family level with DNA-based methods). We do recommend using this approach even if 'speedy' sampling only is possible, but we must highlight that disregarding long-term ecological data may lead to 'hasty' conclusions. So, the ideal scenario is to complement both approaches and integrate the information they generate, always taking into account the ecological significance of the results.

Considering only the results of the classical method, this species diet is very different from the continental congeners. In an arid zone of south-east Iberian Peninsula, the main groups present in the diet of T. mauritanica were Araneae, Homoptera, Lepidoptera and Carabidae larvae, and Formicidae. Considering prey biomass, the larvae of Lepidoptera and Carabidae dominated the diet, being followed by non-Araneae Arachnida, Araneae and Onyscidae and plants were not very important diet items (Hódar \& Pleguezuelos, 1999; Hódar et al., 2006). Similarly, in Central Iberian Peninsula, the most frequent prey were Araneae, Coleoptera, Homoptera, Diptera and Formicidae (Gil, Guerrero \& Perez-Mellado, 1994), while in an anthropic environment (historical centre of Rome, Italy) there was a clear predominance of flying groups like Diptera and Lepidoptera (Capula \& Luiselli, 1994), captured using a sit-and-wait strategy near artificial light. However, none of the previous studies used metabarcoding, so results can differ even further or new groups can, in fact, be more important than the ones identified. In this way, diets can be more similar than previously thought, considering that some of those groups were in fact detected in the diet of the Selvagens geckos using the metabarcoding approach.

The diet of other Macaronesian Tarentola endemics that resulted from the colonization of the Canaries and Cabo Verde archipelagos is still poorly known. With the remarkable exception of the Cabo Verdean Tarentola gigas, all island endemics are somewhat smaller than continental $T$. mauritanica (Pleguezuelos, Márquez \& Lizana, 2004; Vasconcelos et al., 2012). In Raso islet, Mateo et al. (2016), studied the diet of small-sized T. raziana (similar in size to the Selvagens gecko) and the very large-sized $T$. gigas using classical methods and found that the first consisted mainly of insects and other ground arthropods and the latter on vertebrates, but also included arthropods and plants. The main taxa in T. raziana's diet were Coleoptera, followed by Hymenoptera (Mateo et al., 2016), which are also the main preys found in our results using classical methods. The metabarcoding studies of Seguro (2017) on T. raziana and Pinho et al.

PeerJ reviewing PDF | (2019:04:36364:2:1:NEW 18 Oct 2019) 
467 (2018) on T. gigas revealed, similarly to our results, the importance of plants and arthropods on 468 these species diet and also the presence of vertebrate items, which were previously undetected. 469 Moreover, those studies, equally to ours, described the presence of invertebrate groups never 470 formerly reported. Classic studies on the diet of the sympatric Madeira lizard Teira dugesii found 471 that diet mainly consists of Coleoptera and Formicidae species, even though ingestion of plants 472 and seabird juvenile feathers were also reported (Aguilar, 2016; Rund, 2016; Sadek, 1981). 473 These results are also consistent with ours, confirming wider trophic niches of the reptiles 474 occurring on the Macaronesian Islands. In addition, these results highlight the possible resource competition between the two reptile species on Selvagens, even though empirical observations sustain their spatial segregation and distinct activity patterns (Oliveira et al., 2005; Rebelo, 2008). This, together with the possible predation of T. bischoffi by T. dugesii (Oliveira et al., 478 479 2005; Rebelo, 2008) should be further explored.

483

484

485

486

487

488

489

490

491

492

493

494

495

496

497

498

499

500

501

502

503

504

Despite these methodological limitations, metabarcoding studies have proven to, with the appropriate procedures, allow successful detection of a range of taxa identified with classic methods and provide different ecological information (Shaw et al., 2016). DNA-based diet studies have been shown to describe the diet profile of a wide range of species with higher resolution and greater efficacy than classical methodologies, e.g. birds (Trevelline et al., 2016), bats (Hope et al., 2014) and sea lions (Hardy et al., 2017). Therefore, DNA metabarcoding is a valuable and revolutionary tool for conservation research and management (Allendorf \& Luikart, 2009).

\section{Conclusions}

In conclusion, allying classical and DNA-based methods provides a more comprehensive description of a species' diet spectrum, as well as valuable information for the conservation of threatened species. Metabarcoding methods, even when deployed as extremely quick surveys, can deliver holistic results on diet composition, diversity, and ecological networks at relatively low costs (Lopes et al., 2019). In this case, we showed the importance of plants and, to a lesser degree, of vertebrates, for this insular Selvagens gecko. Moreover, metabarcoding provided a large amount of data in a short time without exclusively relying on taxonomic experts. This is important to provide timely information to institutions responsible for species conservation (Ji et al., 2013), especially in areas of difficult access that require urgent conservation actions, as is the case for many remote islands within biodiversity hotspots (Taylor \& Harris, 2012; Thomsen \& Willerslev, 2015). However, for the accurate management of island endemics, one short visit will not be enough. For instance, thorough DNA sampling in different seasons should be considered and good reference collections should be assembled, as for instance most invertebrate species known to occur on Selvagens have no sequences available on GenBank (see Table S4). Likewise, the detected trophic links should be explored to have a clear picture of the functional 
505 relationships of the target species. Based on our results, it is important to clarify whether the 506 links detected between the gecko and Cory's shearwater Calonectris borealis are related to 507 predation or commensalism, as well as if the Selvagens gecko has any role in the pollination or 508 seed dispersal of some of the plants identified in its diet. Shedding light on these questions will 509 have consequences for the conservation of this gecko species and its ecosystem. Our work will 510 contributed to establishing guidelines for future management of the Selvagens gecko and its 511 habitat.

512

513

\section{Acknowledgements}

515 A special thanks to Bruno Carreira for all the help throughout one of the sampling seasons and 516 Pierre Gilles, Conceição Biscoito and Sandro Correia for help during the sampling in 2017. 517 Thanks to Maria M. Romeiras for plant identification. And thanks to the Portuguese Navy and to

518 Yersin's crew for taking us to the study area, which would have been impossible otherwise.

519

520

\section{References}

522

523

524

525

526

527

528

529

530

531

532

533

534

535

536

537

538

539

540

541

542

Acinas SG, Sarma-Rupavtarm R, Klepac-Ceraj V, and Polz MF. 2005. PCR-induced sequence artifacts and bias: insights from comparison of two 16S rRNA clone libraries constructed from the same sample. Applied and environmental microbiology 71:8966-8969. 10.1128/AEM.71.12.8966-8969.2005

Aguilar F. 2016. Qual o papel trófico da lagartixa-da-Madeira, Teira dugesii selvagensis, na Selvagem Grande? Mestrado em Biologia da Conservação. Faculdade de Ciências da Universidade de Lisboa.

Alcover JA, and McMinn M. 1994. Predators of Vertebrates on Islands: In many insular faunas, birds (and less commonly mammals and reptiles) prey on middle- and large-size vertebrates. BioScience 44:12-18. 10.2307/1312401

Allendorf FW, and Luikart G. 2009. Conservation and the genetics of populations: John Wiley $\&$ Sons.

Amend AS, Seifert KA, and Bruns TD. 2010. Quantifying microbial communities with 454 pyrosequencing: does read abundance count? Molecular ecology 19:5555-5565. 10.1111/j.1365-294X.2010.04898.x

Boieiro M, Fagundes AI, Gouveia C, Ramos JA, and Menezes D. 2018. Small but fierce: invasive ants kill Barolo Shearwater (Puffinus lherminieri baroli) nestling in Cima islet (Porto Santo, Madeira Archipelago). AIRO - Portuguese Society for the Study of Birds 25:44-50.

Borges P, Abreu C, Aguiar AF, Carvalho P, Jardim R, Melo I, Oliveira P, Sérgio C, Serrano A, and Vieira P. 2008a. The arthropods (Arthropoda) of the Madeira and Selvagens

Peer) reviewing PDF | (2019:04:36364:2:1:NEW 18 Oct 2019) 
543

544

545

546

547

548

549

550

551

552

553

554

555

556

557

558

559

560

561

562

563

564

565

566

567

568

569

570

571

572

573

574

575

576

577

578

579

580

581

582

583

584

585

586

archipelagos. A list of the terrestrial fungi, flora and fauna of Madeira and Selvagens archipelagos. Direcção Regional do Ambiente da Madeira and Universidade dos Açores, Funchal and Angra do Heroísmo, 245.

Borges P, Abreu C, Aguiar AF, Carvalho P, Jardim R, Melo I, Oliveira P, Sérgio C, Serrano A, and Vieira P. 2008b. A list of the terrestrial fungi, flora and fauna of Madeira and Selvagens archipelagos.

Briggs AA, Young HS, McCauley DJ, Hathaway SA, Dirzo R, and Fisher RN. 2012. Effects of Spatial Subsidies and Habitat Structure on the Foraging Ecology and Size of Geckos. PloS one 7:e41364. 10.1371/journal.pone.0041364

Brock KM, Donihue CM, and Pafilis P. 2014. New records of frugivory and ovophagy in Podarcis (Lacertidae) lizards from East Mediterranean Islands. North-Western Journal of Zoology 10:223-225.

Brown DS, Jarman SN, and Symondson WO. 2012. Pyrosequencing of prey DNA in reptile faeces: analysis of earthworm consumption by slow worms. Molecular Ecology Resources 12:259-266. 10.1111/j.1755-0998.2011.03098.x

Capula M, and Luiselli L. 1994. Resource partitioning in a Mediterranean lizard community. Bolletino di zoologia 61:173-177. 10.1080/11250009409355879

Carranza S, Arnold E, Mateo JA, and López-Jurado LF. 2000. Long-distance colonization and radiation in gekkonid lizards, Tarentola (Reptilia: Gekkonidae), revealed by mitochondrial DNA sequences. Proceedings of the Royal Society of London B: Biological Sciences 267:637-649. 10.1098/rspb.2000.1050

Carranza S, Arnold EN, Thomas RH, and López-Jurado LF. 1999. Status of the extinct giant lacertid lizard Gallotia simonyi simonyi (Reptilia: Lacertidae) assessed using mtDNA sequences from museum specimens. Herpetological Journal 9(2):83-86. 10.1111/j.10958312.2003.00265.x

Carretero MA, and Lo Cascio P. 2010. What do myrmecophagous geckos eat when ants are not available?: comparative diets of three Socotran species. African Zoology 45:115-120. $10.3377 / 004.045 .0107$

Caujapé-Castells J, Tye A, Crawford DJ, Santos-Guerra A, Sakai A, Beaver K, Lobin W, Vincent Florens FB, Moura M, Jardim R, Gómes I, and Kueffer C. 2010. Conservation of oceanic island floras: Present and future global challenges. Perspectives in Plant Ecology, Evolution and Systematics 12:107-129. 10.1016/j.ppees.2009.10.001

Crochet P-A, and Renoult JP. 2008. Tarentola annularis annularis (Geoffroy de Saint-Hilaire, 1827) preying on a mammal. Herpetology Notes 1:58-59.

Folmer O, Black M, Hoeh W, Lutz R, and Vrijenhoek R. 1994. DNA primers for amplification of mitochondrial cytochrome c oxidase subunit I from diverse metazoan invertebrates. Molecular Marine Biology and Biotechnology 3:294-299.

Frankham R. 1997. Do island populations have less genetic variation than mainland populations? Heredity 78. 10.1038/hdy.1997.46

Gil MJ, Guerrero F, and Perez-Mellado V. 1994. Seasonal variation in diet composition and prey selection in the mediterranean gecko Tarentola mauritanica. Israel Journal of Zoology 40:61-74. 10.1080/00212210.1994.10688735

Godínez-Álvarez H. 2004. Pollination and seed dispersal by lizards: a review. Revista Chilena de Historia Natural 77:569-577. 10.4067/S0716-078X2004000300015 
587 Granadeiro JP, Dias MP, Rebelo R, Santos CD, and Catry P. 2006. Numbers and population 588 trends of Cory's shearwater Calonectris diomedea at Selvagem Grande, Northeast Atlantic. Waterbirds 29:56-60. www.jstor.org/stable/4132605.

Greenville A, and Dickman C. 2005. The ecology of Lerista labialis (Scincidae) in the Simpson Desert: reproduction and diet. Journal of Arid Environments 60:611-625. 10.1016/j.jaridenv.2004.07.010

Hardy N, Berry T, Kelaher BP, Goldsworthy SD, Bunce M, Coleman MA, Gillanders BM, Connell SD, Blewitt M, and Figueira W. 2017. Assessing the trophic ecology of top predators across a recolonisation frontier using DNA metabarcoding of diets. Marine Ecology Progress Series 573:237-254. 10.3354/meps12165

Hódar J, and Pleguezuelos J. 1999. Diet of the Moorish gecko Tarentola mauritanica in an arid zone of south-eastern Spain. Herpetological journal 9:29-32.

Hódar J, Pleguezuelos J, Villafranca C, and Fernández-Cardenete J. 2006. Foraging mode of the Moorish gecko Tarentola mauritanica in an arid environment: inferences from abiotic setting, prey availability and dietary composition. Journal of Arid Environments 65:8393. 10.1016/j.jaridenv.2005.08.006

Hope PR, Bohmann K, Gilbert MTP, Zepeda-Mendoza ML, Razgour O, and Jones G. 2014. Second generation sequencing and morphological faecal analysis reveal unexpected foraging behaviour by Myotis nattereri (Chiroptera, Vespertilionidae) in winter. Frontiers in zoology 11:39. 10.1186/1742-9994-11-39

Ibrahim AA. 2004. Behavioural ecology of the White-spotted Gecko, Tarentola annularis (Reptilia: Gekkonidae), in Ismailia City, Egypt. Zoology in the Middle East 31:23-38. 10.1080/09397140.2004.10638019

BirdLife International 2019. Important Bird Areas factsheet: Selvagens - Oceânica. Available at http://www.birdlife.org (accessed 11 June 2019).

James CD. 1991. Temporal variation in diets and trophic partitioning by coexisting lizards (Ctenotus: Scincidae) in central Australia. Oecologia 85:553-561. 10.1007/BF00323768

Jarman SN, McInnes JC, Faux C, Polanowski AM, Marthick J, Deagle BE, Southwell C, and Emmerson L. 2013. Adélie Penguin Population Diet Monitoring by Analysis of Food DNA in Scats. PloS one 8. 10.1371/journal.pone.0082227

Ji Y, Ashton L, Pedley SM, Edwards DP, Tang Y, Nakamura A, Kitching R, Dolman PM, Woodcock P, Edwards FA, Larsen TH, Hsu WW, Benedick S, Hamer KC, Wilcove DS, Bruce C, Wang X, Levi T, Lott M, Emerson BC, and Yu DW. 2013. Reliable, verifiable and efficient monitoring of biodiversity via metabarcoding. Ecology letters 16:12451257. doi:10.1111/ele.12162

Kartzinel TR, and Pringle RM. 2015. Molecular detection of invertebrate prey in vertebrate diets: trophic ecology of Caribbean island lizards. Molecular Ecology Resources 15:903-914. 10.1111/1755-0998.12366

Lopes RJ, Pinho CJ, Santos B, Seguro M, Mata VA, Egeter B, and Vasconcelos R. 2019. Intricate trophic links between threatened vertebrates confined to a small island in the Atlantic Ocean. Ecology and Evolution 9:4994-5002. 10.1002/ece3.5105

Martin-Laurent F, Philippot L, Hallet S, Chaussod R, Germon J, Soulas G, and Catroux G. 2001. DNA extraction from soils: old bias for new microbial diversity analysis methods. Applied and environmental microbiology 67:2354-2359. 10.1128/AEM.67.5.23542359.2001 
632 Mateo JA, Geniez P, Hernández-Acosta CN, and López-Jurado LF. 2016. ¿Realmente importa 633 tanto el tamaño?: la dieta de las dos especies del género Tarentola de la Isla de Raso

634

635

636

637

638

639

640

641

642

643

644

645

646

647

648

649

650

651

652

653

654

655

656

657

658

659

660

661

662

663

664

665

666

667

668

669

670

671

672

673

674

675

676

677

(Cabo Verde). Boletín de la Asociación Herpetológica Española 27:19-23.

Matias R, Rebelo R, Granadeiro J, and Catry P. 2009. Predation by Madeiran wall lizards Teira dugesii on Cory's shearwater Calonectris diomedea hatchlings at Selvagem Grande, North Atlantic. Waterbirds 32:600-604. 10.1675/063.032.0415

Miranda EBP. 2017. The Plight of Reptiles as Ecological Actors in the Tropics. Frontiers in Ecology and Evolution 5:159. 10.3389/fevo.2017.00159

Murray BR, and Dickman CR. 1994. Granivory and microhabitat use in Australian desert rodents: are seeds important? Oecologia 99:216-225. 10.1007/BF00627733

Neves VC, Nava C, Monteiro EV, Monteiro PR, and Bried J. 2017. Depredation of Monteiro's Storm-Petrel (Hydrobates monteiroi) Chicks by Madeiran Wall Lizards (Lacerta dugesii). Waterbirds 40:82-87. doi.org/10.1675/063.040.0113

Oliveira ME, Loureiro A, Martins HR, Pargana J, Brito JC, Teixeira J, Ferrand de Almeida N, Paulo O, Rito P, and Dellinger T. 2005. Répteis. In: Cabral MJ, Almeida J, Almeida PR, Dellinger T, Ferrand de Almeida N, Oliveira M, Palmeirim J, Queirós AI, Rogado L, and Santos-Reis M, eds. Livro vermelho dos vertebrados de Portugal: Instituto da Conservação da Natureza.

Olivera P, Menezes D, Trout R, Buckle A, Geraldes P, and Jesus J. 2010. Successful eradication of the European rabbit (Oryctolagus cuniculus) and house mouse (Mus musculus) from the island of Selvagem Grande (Macaronesian archipelago), in the Eastern Atlantic. Integrative zoology 1:70-83. 10.1111/j.1749-4877.2010.00186.x

Penado A, Rocha R, Sampaio M, Gil V, Carreira BM, and Rebelo R. 2015. Where to "Rock"? Choice of retreat sites by a gecko in a semi-arid habitat. Acta Herpetologica 10:47-54. 10.13128/Acta_Herpetol-15304

Pérez-Mellado V, and Corti C. 1993. Dietary adaptations and herbivory in lacertid lizards of the genus Podarcis from western Mediterranean islands (Reptilia: Sauria). Bonn Zool Beitr 44:193-220.

Pérez-Mellado V, Pérez-Cembranos A, Garrido M, Luiselli L, and Corti C. 2011. Using faecal samples in lizard dietary studies. Amphibia-Reptilia 32:1-7. 10.1163/017353710X530212

Pietruszka RD, Hanrahan SA, Mitchell D, and Seely MK. 1986. Lizard herbivory in a sand dune environment: the diet of Angolosaurus skoogi. Oecologia 70:587-591. 10.1007/bf00379909

Pinho CJ, Santos B, Mata VA, Seguro M, Romeiras MM, Lopes RJ, and Vasconcelos R. 2018. What Is the Giant Wall Gecko Having for Dinner? Conservation Genetics for Guiding Reserve Management in Cabo Verde. Genes 9:599. 10.3390/genes9120599

Pinkas L. 1971. Food habits of Albacore Bluefin, tuna and bonito in California waters. California Department Fish Game - Fish Bulletin 152:1-350.

Piñol J, Mir G, Gomez-Polo P, and Agustí N. 2015. Universal and blocking primer mismatches limit the use of high-throughput DNA sequencing for the quantitative metabarcoding of arthropods. Molecular ecology resources 15:819-830. 10.1111/1755-0998.12355

Pleguezuelos JM, Márquez R, and Lizana M. 2004. Atlas y libro rojo de los anfibios y reptiles de España: Organismo Autónomo de Parques Nacionales.

Plentovich S, Russell T, and Fejeran CC. 2018. Yellow crazy ants (Anoplolepis gracilipes) reduce numbers and impede development of a burrow-nesting seabird. Biological Invasions 20:77-86. 10.1007/s10530-017-1516-z

Peer] reviewing PDF | (2019:04:36364:2:1:NEW 18 Oct 2019) 
678 Polz MF, and Cavanaugh CM. 1998. Bias in template-to-product ratios in multitemplate PCR.

$679 \quad$ Applied and environmental Microbiology 64:3724-3730.

680

681

682

683

684

685

686

687

688

689

690

691

692

693

694

695

696

697

698

699

700

701

702

703

704

705

706

707

708

709

710

711

712

713

714

715

716

717

718

719

720

721

722

Pompanon F, Deagle BE, Symondson WOC, Brown DS, Jarman SN, and Taberlet P. 2012. Who is eating what: diet assessment using next generation sequencing. Molecular ecology 21:1931-1950. 10.1111/j.1365-294X.2011.05403.x

Porazinska DL, Sung W, Giblin-Davis RM, and Thomas WK. 2010. Reproducibility of read numbers in high-throughput sequencing analysis of nematode community composition and structure. Molecular Ecology Resources 10:666-676. 10.1111/j.17550998.2009.02819.x

Rato C, Carranza S, and Harris DJ. 2012. Evolutionary history of the genus Tarentola (Gekkota: Phyllodactylidae) from the Mediterranean Basin, estimated using multilocus sequence data. BMC Evolutionary Biology 12:14. 10.1186/1471-2148-12-14

Rebelo R. 2008. Tarentola bischoffi. In: Loureiro A, Ferrand de Almeida N, Carretero M, and Paulo O, eds. Atlas dos anfibios e répteis de Portugal. Lisboa: Instituto da Conservação da Natureza e da Biodiversidade, 188-189.

Rodríguez A, Nogales M, Rumeu B, and Rodríguez B. 2008. Temporal and spatial variation in the diet of the endemic lizard Gallotia galloti in an insular Mediterranean scrubland. Journal of Herpetology 42:213-223. doi.org/10.1670/07-0752.1

Romeiras MM, Monteiro F, Duarte MC, Schaefer H, and Carine M. 2015. Patterns of genetic diversity in three plant lineages endemic to the Cape Verde Islands. AoB PLANTS 7. 10.1093/aobpla/plv051

Rund D. 2016. Feeding ecology and molecular survey of Hepatozoon infection of Lacerta dugesii in the Azores. University of Gießen.

Sadek RA. 1981. The diet of the Madeiran lizard Lacerta dugesii. Zoological Journal of the Linnean Society 73:313-341. 10.1111/j.1096-3642.1981.tb01599.x

Sagonas K, Pafilis P, Lymberakis P, and Valakos ED. 2015. Trends and patterns in the feeding ecology of the widespread Balkan green lizard Lacerta trilineata (Squamata: Lacertidae) in insular and continental Greece. North-Western Journal of Zoology 11:117-126.

Schleich H. 1984. Die Geckos der Gattung Tarentola der Kapverden (Reptilia: Sauria: Gekkonidae). Courier Forschungsinstitut Senckenberg 68:95-106.

Seguro M. 2017. Unravelling the ecology of the Raso wall gecko (Tarentola raziana) through metabarcoding Licenciatura em Biologia. Faculdade de Ciências da Universidade do Porto.

Shaw JLA, Clarke LJ, Wedderburn SD, Barnes TC, Weyrich LS, and Cooper A. 2016. Comparison of environmental DNA metabarcoding and conventional fish survey methods in a river system. Biological Conservation 197:131-138. 10.1016/j.biocon.2016.03.010

Sim-Sim M, Ruas S, Fontinha S, Hedenäs L, Sérgio C, and Lobo C. 2014. Bryophyte conservation on a North Atlantic hotspot: threatened bryophytes in Madeira and Selvagens Archipelagos (Portugal). Systematics and Biodiversity 12:315-330. 10.1080/14772000.2014.918063

Taberlet P, Coissac E, Pompanon F, Gielly L, Miquel C, Valentini A, Vermat T, Corthier G, Brochmann C, and Willerslev E. 2007. Power and limitations of the chloroplast trn L (UAA) intron for plant DNA barcoding. Nucleic Acids Research 35:14. 10.1093/nar/gk1938

Peer) reviewing PDF | (2019:04:36364:2:1:NEW 18 Oct 2019) 
723

724

725

726

727

728

729

730

731

732

733

734

735

736

737

738

739

740

741

742

743

744

745

746

747

748

749

750

751
Taberlet P, Gielly L, Pautou G, and Bouvet J. 1991. Universal primers for amplification of three non-coding regions of chloroplast DNA. Plant molecular biology 17:1105-1109. 10.1007/BF00037152

Taylor HR, and Harris WE. 2012. An emergent science on the brink of irrelevance: a review of the past 8 years of DNA barcoding. Molecular Ecology Resources 12:377-388. 10.1111/j.1755-0998.2012.03119.x

Thomsen PF, and Willerslev E. 2015. Environmental DNA - An emerging tool in conservation for monitoring past and present biodiversity. Biological Conservation 183:4-18. 10.1016/j.biocon.2014.11.019

Trevelline BK, Latta SC, Marshall LC, Nuttle T, and Porter BA. 2016. Molecular analysis of nestling diet in a long-distance Neotropical migrant, the Louisiana Waterthrush (Parkesia motacilla). The Auk 133:415-428. 10.1642/AUK-15-222.1

Vasconcelos R, Carranza S, and James Harris D. 2010. Insight into an island radiation: the Tarentola geckos of the Cape Verde archipelago. Journal of Biogeography 37:10471060. 10.1111/j.1365-2699.2009.02254.x

Vasconcelos R, Perera A, Geniez P, Harris DJ, and Carranza S. 2012. An integrative taxonomic revision of the Tarentola geckos (Squamata, Phyllodactylidae) of the Cape Verde Islands. Zoological Journal of the Linnean Society 164:328-360. 10.1111/j.10963642.2011.00768.x

Vestheim H, and Jarman SN. 2008. Blocking primers to enhance PCR amplification of rare sequences in mixed samples - a case study on prey DNA in Antarctic krill stomachs. Frontiers in zoology 5:12. 10.1186/1742-9994-5-12

Vitt LJ, and Caldwell JP. 2013. Herpetology: an introductory biology of amphibians and reptiles: Academic press.

Whittaker RJ, and Fernández-Palacios JM. 2007. Island biogeography: ecology, evolution, and conservation: Oxford University Press.

Whittaker RJ, Fernández-Palacios JM, Matthews TJ, Borregaard MK, and Triantis KA. 2017. Island biogeography: Taking the long view of nature's laboratories. Science 357.

Zar JH. 2010. Biostatistical Analysis. New Jersey. 


\section{Table $\mathbf{1}$ (on next page)}

Taxa collected for the classical and metabarcoding reference collection

(A) Number of arthropods collected per pitfall in the first two sampling seasons (September 2010 and May 2011). In September 2017 we only recorded the presence of each arthropod category for the DNA reference collection. (B) Plant and vertebrate sampled for the DNA reference collection. $\mathrm{NI}$ stands for non-identified preys and $\bullet$ for prey presence. 


\begin{tabular}{|c|c|c|c|c|c|}
\hline \multicolumn{4}{|l|}{ A } & \multicolumn{2}{|l|}{ B } \\
\hline Taxonomic category & $09 / 10$ & $05 / 11$ & $09 / 17$ & Taxonomic category & $09 / 17$ \\
\hline \multicolumn{4}{|l|}{ Arachnida } & \multicolumn{2}{|l|}{ Magnoliopsida } \\
\hline NI Acari & 0 & 2 & & Apiales & \\
\hline Pseudoscorpiones & & & & Apiaceae & \\
\hline Cheliferidae & 1 & 1 & & Astydamia latifolia & • \\
\hline Araneae & & & & Asterales & \\
\hline Gnaphosidae & 7 & 2 & & Asteraceae & \\
\hline Salticidae & - & - & $\bullet$ & Senecio incrassatus & $\bullet$ \\
\hline \multicolumn{4}{|l|}{ Insecta } & \multicolumn{2}{|l|}{$\begin{array}{l}\text { Caryophyllales } \\
\text { Aizoaceae }\end{array}$} \\
\hline Coleoptera & & & & Aizoaceae & \\
\hline Carabidae & 5 & 2 & - & Aizoon canariensis & • \\
\hline NI Sp. A & 1 & 0 & & Mesembryanthemum sp. & - \\
\hline Tenebrionidae & & & & Amaranthaceae & \\
\hline Hegeter latebricola & - & - & - & Chenopodium coronopus & • \\
\hline Diptera & & & & Fabales & \\
\hline Dolichopodidae & 2 & 3 & & Fabaceae & \\
\hline Hybotidae & 2 & 0 & & Lotus glaucus & • \\
\hline Limoniidae & 1 & 0 & & Solanales & \\
\hline NI Sp. C & 6 & 18 & & Solanaceae & \\
\hline Hemiptera & & & & Lycopersicon esculentum & • \\
\hline Aphididae & 0 & 1 & & Solanum nigrum & - \\
\hline Cicadellidae & - & - & - & Gentianales & \\
\hline Hymenoptera & & & & Apocynaceae & \\
\hline Formicidae & 213 & 147 & - & Periploca laevigata & - \\
\hline \multicolumn{6}{|l|}{ Isopoda } \\
\hline Porcellionidae & - & - & - & & \\
\hline \multicolumn{6}{|l|}{ Lepidoptera } \\
\hline Cosmopterigidae & - & - & - & Aves & \\
\hline Pyralidae & - & - & • & Procellariiformes & \\
\hline Psocoptera & & & & Procellariidae & \\
\hline Ectopsodidae & 1 & 0 & & Bulweria bulwerii & - \\
\hline Psyllipsocidae & 32 & 1 & & Calonectris borealis & - \\
\hline \multicolumn{6}{|l|}{ Zygentoma } \\
\hline Lepismatidae & 2 & 0 & $\bullet$ & & \\
\hline \multicolumn{6}{|l|}{ Chilopoda } \\
\hline \multicolumn{6}{|l|}{ Scutigeromorpha } \\
\hline Scutigera coleoptrata & - & - & $\bullet$ & & \\
\hline
\end{tabular}




\section{Table 2 (on next page)}

Composition of the diet of Selvagem gecko Tarentola bischoffi according to the classic and metabarcoding methods

The three sampling periods were September 2010, May 2011 and September 2017 (the latter with metabarcoding). \% N, percentage number; \% B, percentage of biomass; RII, relative importance index; \% FO, frequency of occurrence; $\mathrm{NI}$, not identified. 


\begin{tabular}{|c|c|c|c|c|c|c|c|c|c|}
\hline \multirow{2}{*}{ Taxonomic category } & \multicolumn{2}{|c|}{$\% \mathrm{~N}$} & \multicolumn{2}{|c|}{$\%$ B } & \multicolumn{2}{|c|}{ RII } & \multicolumn{3}{|c|}{$\%$ FO } \\
\hline & $09 / 10$ & $05 / 11$ & $09 / 10$ & $05 / 11$ & $09 / 10$ & $05 / 11$ & $09 / 10$ & $05 / 11$ & $09 / 17$ \\
\hline \multicolumn{10}{|l|}{ Arthropoda } \\
\hline \multicolumn{10}{|l|}{ Arachnida } \\
\hline \multicolumn{10}{|l|}{ Araneae } \\
\hline Philodromidae & - & - & - & - & - & - & - & - & 3.70 \\
\hline NI (Acari) & 0.72 & 0 & 0.03 & 0 & 4.69 & 0 & 6.25 & 0 & - \\
\hline Pseudoscorpiones & & & & & & & & & 0.00 \\
\hline Cheliferidae & 1.44 & 1.08 & 0.06 & 0.01 & 18.77 & 3.3 & 12.5 & 3.03 & - \\
\hline \multicolumn{10}{|l|}{ Insecta } \\
\hline Blattodea NI & - & - & - & - & - & - & - & - & 3.70 \\
\hline \multicolumn{10}{|l|}{ Coleoptera } \\
\hline Anobidae & 2.16 & 0.54 & - & - & - & - & 18.75 & 1.52 & - \\
\hline Carabidae & 3.6 & 16.76 & 95.67 & 98.98 & 3102.18 & 4559.1 & 31.25 & 39.39 & 29.63 \\
\hline Chrysomelidae & - & - & - & - & - & - & - & - & 3.70 \\
\hline Coccinelidae & 0.72 & 0 & - & - & - & - & 6.25 & 0 & - \\
\hline Curculionidae & 0.72 & 0 & - & - & - & - & 6.25 & 0 & - \\
\hline Lycidae & - & - & - & - & - & - & - & - & 11.11 \\
\hline Sp. A & 0 & 14.59 & 0 & 0.14 & 0 & 401.64 & 0 & 27.27 & - \\
\hline Sp. B & 5.04 & 11.89 & - & - & - & - & 43.75 & 24.24 & - \\
\hline Scarabaeidae & - & - & - & - & - & - & - & - & 7.41 \\
\hline Staphylinidae & 0.72 & 0 & - & - & - & - & 6.25 & 0 & 3.70 \\
\hline Tenebrionidae & 1.44 & 0 & - & - & - & - & 12.5 & 0 & 11.11 \\
\hline $\mathrm{NI}$ & - & - & - & - & - & - & - & - & 11.11 \\
\hline \multicolumn{10}{|l|}{ Diptera } \\
\hline Cecidomyiidae & - & - & - & - & - & - & - & - & 3.70 \\
\hline Chironomidae & - & - & - & - & - & - & - & - & 18.52 \\
\hline Culicidae & - & - & - & - & - & - & - & - & 33.33 \\
\hline Limoniidae & - & - & - & - & - & - & - & - & 3.70 \\
\hline Muscidae & - & - & - & - & - & - & - & - & 11.11 \\
\hline Psychodidae & - & - & - & - & - & - & - & - & 3.70 \\
\hline Sciaridae & - & - & - & - & - & - & - & - & 7.41 \\
\hline $\mathrm{NI}$ & 0 & 9.73 & 0 & 0.49 & 0 & 263.21 & 0 & 25.75 & 3.70 \\
\hline \multicolumn{10}{|l|}{ Hemiptera } \\
\hline Acanthosomatidae & - & - & - & - & - & - & - & - & 7.41 \\
\hline Aphididae & 0 & 1.08 & 0 & 0.01 & 0 & 3.3 & 0 & 3.03 & 3.70 \\
\hline Cicadellidae & - & - & - & - & - & - & - & - & 7.41 \\
\hline Flatidae & - & - & - & - & - & - & - & - & 14.81 \\
\hline Lygaeidae & - & - & - & - & - & - & - & - & 25.93 \\
\hline Miridae & - & - & - & - & - & - & - & - & 3.70 \\
\hline Pteromalidae & - & - & - & - & - & - & - & - & 3.70 \\
\hline NI (Homoptera) & 1.44 & 0 & - & - & - & - & 12.5 & 0 & - \\
\hline $\mathrm{NI}$ & - & - & - & - & - & - & - & - & 7.41 \\
\hline Lepidoptera & & & & & & & & & \\
\hline Lycaenidae & - & - & - & - & - & - & - & - & 3.70 \\
\hline Noctuidae & - & - & - & - & - & - & - & - & 11.11 \\
\hline Tortricidae & - & - & - & - & - & - & - & - & 3.70 \\
\hline NI & - & - & - & - & - & - & - & - & 44.44 \\
\hline Hymenoptera & & & & & & & & & \\
\hline Formicidae & 82.01 & 29.73 & 4.24 & 0.34 & 7007.66 & 774.63 & 81.25 & 25.76 & 7.41 \\
\hline Pteromalidae & - & - & - & - & - & - & - & - & 3.70 \\
\hline Psocoptera & & & & & & & & & \\
\hline Psyllipsocidae & 0 & 2.7 & 0 & 0.03 & 0 & 8.26 & 0 & 3.03 & - \\
\hline Trogiidae & - & - & - & - & - & - & - & - & 25.93 \\
\hline NI & 0 & 11.89 & - & - & - & - & 0 & 24.24 & 3.70 \\
\hline Zygentoma & & & & & & & & & \\
\hline Lepismatidae & - & - & - & - & - & - & - & - & 25.93 \\
\hline NI & & & & & & & & & 7.41 \\
\hline Malacostraca & & & & & & & & & \\
\hline NI & - & - & - & - & - & - & - & - & 7.41 \\
\hline Decapoda & & & & & & & & & \\
\hline NI & - & - & - & - & - & - & - & - & 7.41 \\
\hline Isopoda & & & & & & & & & \\
\hline Porcellionidae & - & - & - & - & - & - & - & - & 7.41 \\
\hline NI & - & - & - & - & - & - & - & - & 7.41 \\
\hline
\end{tabular}

1 


\begin{tabular}{|c|c|c|c|}
\hline \multirow{2}{*}{ Taxonomic category } & \multicolumn{3}{|c|}{$\% \mathrm{FO}$} \\
\hline & $09 / 10$ & $05 / 11$ & $09 / 17$ \\
\hline \multicolumn{4}{|l|}{ Tracheophyta } \\
\hline \multicolumn{4}{|l|}{ Capparales } \\
\hline \multicolumn{4}{|l|}{ Brassicaceae } \\
\hline Lobularia & - & - & 29.63 \\
\hline \multicolumn{4}{|l|}{ Liliopsida } \\
\hline \multicolumn{4}{|l|}{ Poales } \\
\hline Poaceae & - & - & 40.74 \\
\hline \multicolumn{4}{|l|}{ Magnoliopsida } \\
\hline \multicolumn{4}{|l|}{ Apiales } \\
\hline Apiaceae & - & - & 14.81 \\
\hline \multicolumn{4}{|l|}{ Asterales } \\
\hline \multirow{2}{*}{\multicolumn{4}{|c|}{ Caryophyllales }} \\
\hline & & & \\
\hline Aizoaceae & - & - & 33.33 \\
\hline Plumbaginaceae & - & - & 44.44 \\
\hline Amaranthaceae & - & - & 40.74 \\
\hline \multicolumn{4}{|l|}{ Cucurbitales } \\
\hline Cucurbitaceae & - & - & 3.70 \\
\hline \multicolumn{4}{|l|}{ Ericales } \\
\hline Ericaceae & - & - & 3.70 \\
\hline Theaceae & - & - & 3.70 \\
\hline Actinidiaceae & - & - & 11.11 \\
\hline \multicolumn{4}{|l|}{ Fabales } \\
\hline Fabaceae & - & - & 14.81 \\
\hline \multicolumn{4}{|l|}{ Lamiales } \\
\hline Oleaceae & - & - & 3.70 \\
\hline Plantaginaceae & - & - & 3.70 \\
\hline \multicolumn{4}{|l|}{ Malvales } \\
\hline Malvaceae & - & - & 3.70 \\
\hline \multicolumn{4}{|l|}{ Rosales } \\
\hline Moraceae & - & - & 3.70 \\
\hline Rosaceae & - & - & 7.41 \\
\hline \multicolumn{4}{|l|}{ Sapindales } \\
\hline Anacardiaceae & - & - & 3.70 \\
\hline \multicolumn{4}{|l|}{ Solanales } \\
\hline Convolvulaceae & - & - & 3.70 \\
\hline Solanaceae & - & - & 14.81 \\
\hline \multicolumn{4}{|l|}{ Zygophyllales } \\
\hline Zygophyllaceae & - & - & 3.70 \\
\hline Chordata & & & \\
\hline Actinopterygii & & & \\
\hline Perciformes & & & \\
\hline Scombridae & - & - & 3.70 \\
\hline Syngnathiformes & & & \\
\hline Centriscidae & - & - & 3.70 \\
\hline Aves & & & \\
\hline Charadriiformes & - & - & 3.70 \\
\hline Procellariiformes & & & \\
\hline Procellariidae & - & - & 11.11 \\
\hline Reptilia & & & \\
\hline Testudines & & & \\
\hline Cheloniidae & - & - & 3.70 \\
\hline
\end{tabular}


Figure 1

\section{Study Area}

Location of the Selvagens Archipelago in the East Atlantic coast and of the Selvagem Grande Island in the archipelago.
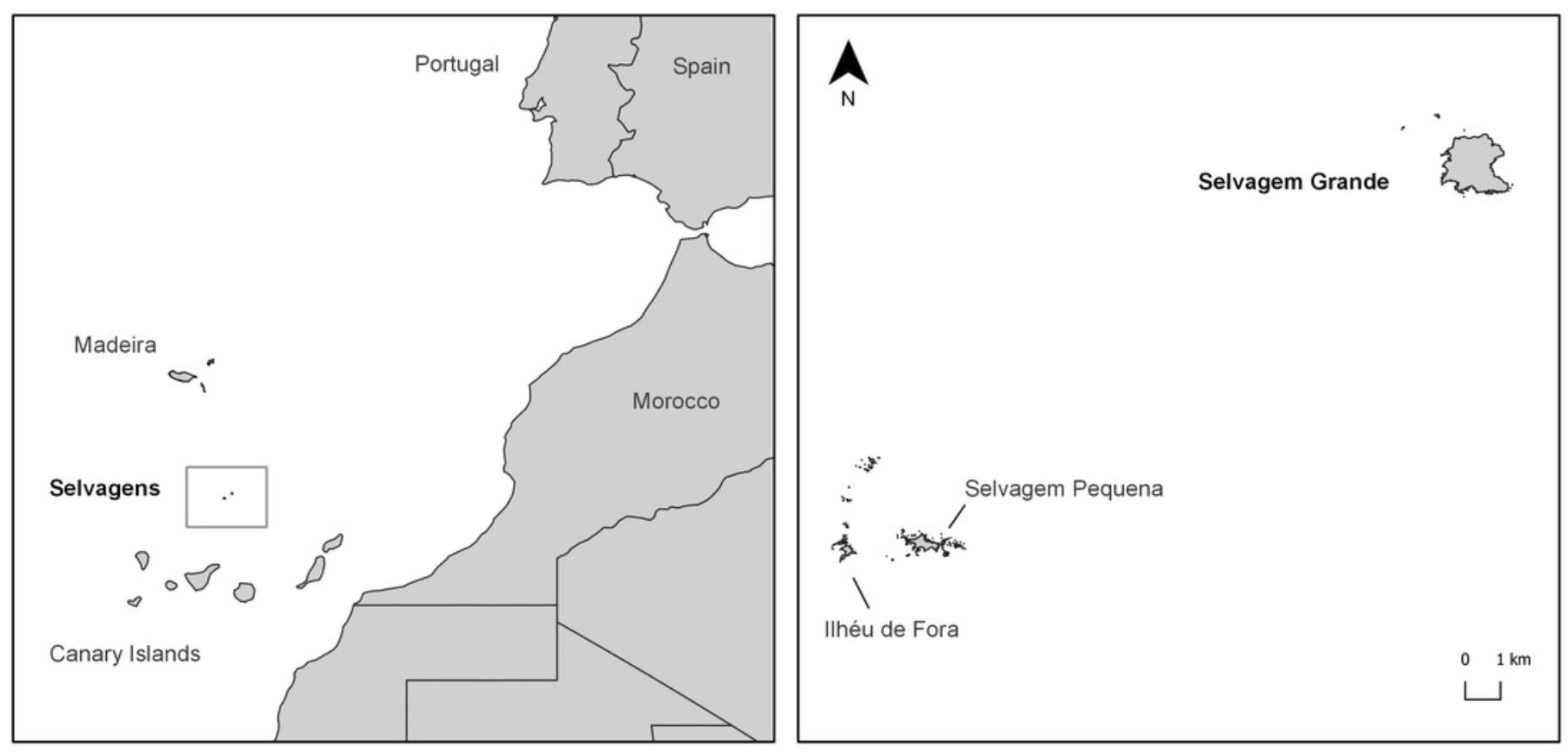
Figure 2

Invertebrate families detected with classical and metabarcoding methods.

Results from September 2010 (in white) and May 2011 (in black) are depicted in the bars on the left and data from September 2017 (in grey) is depicted in the bars on the right. Check Table 2 for further details.

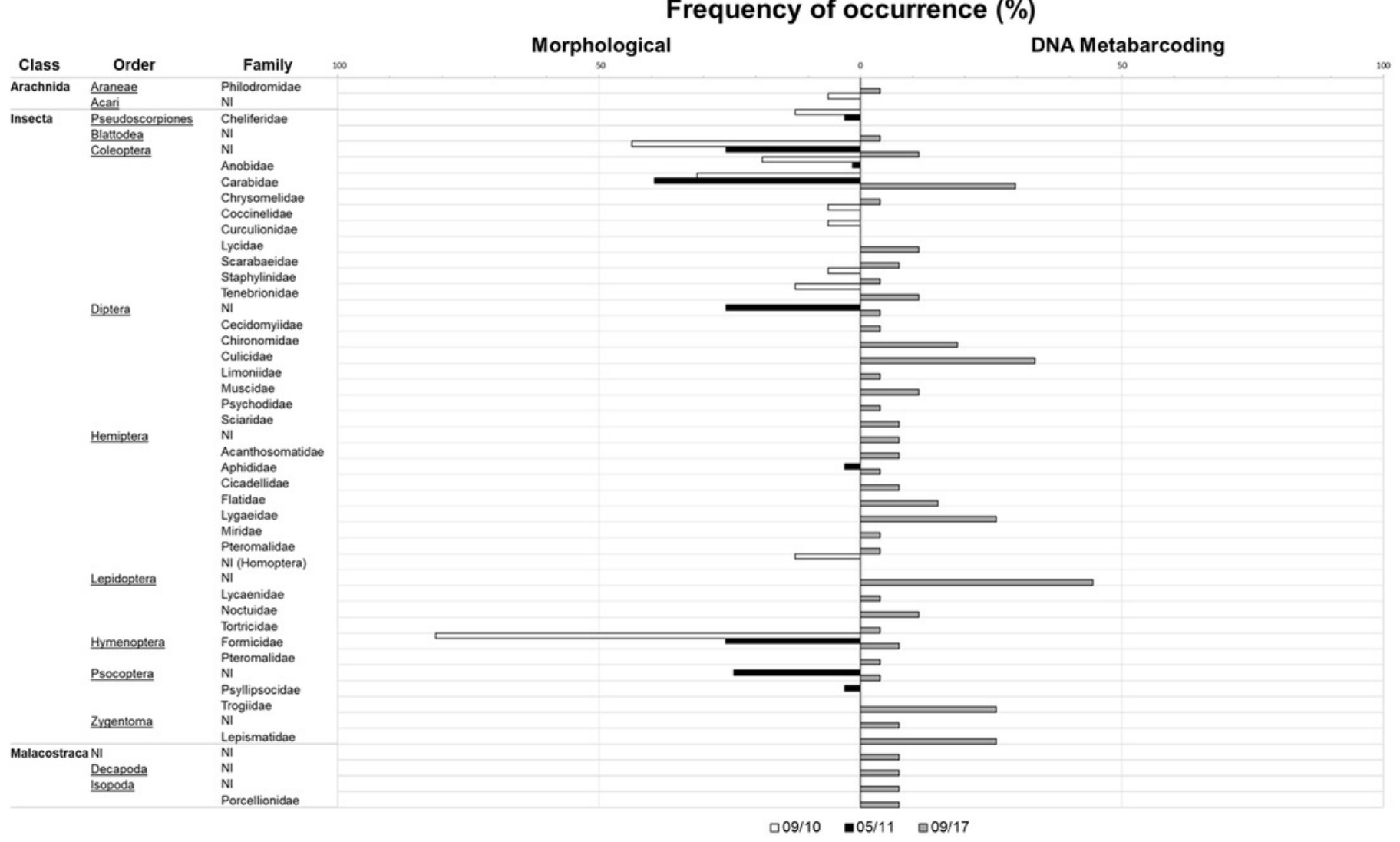


Figure 3

Taxa accumulation curves at family level for the three sampling periods

Data is presented for September 2010 and 2017 and May 2011. Data resulting from classic morphological studies corresponds to 2010 and 2011 (left y-axis) and for metabarcoding to September 2017 (right y-axis).

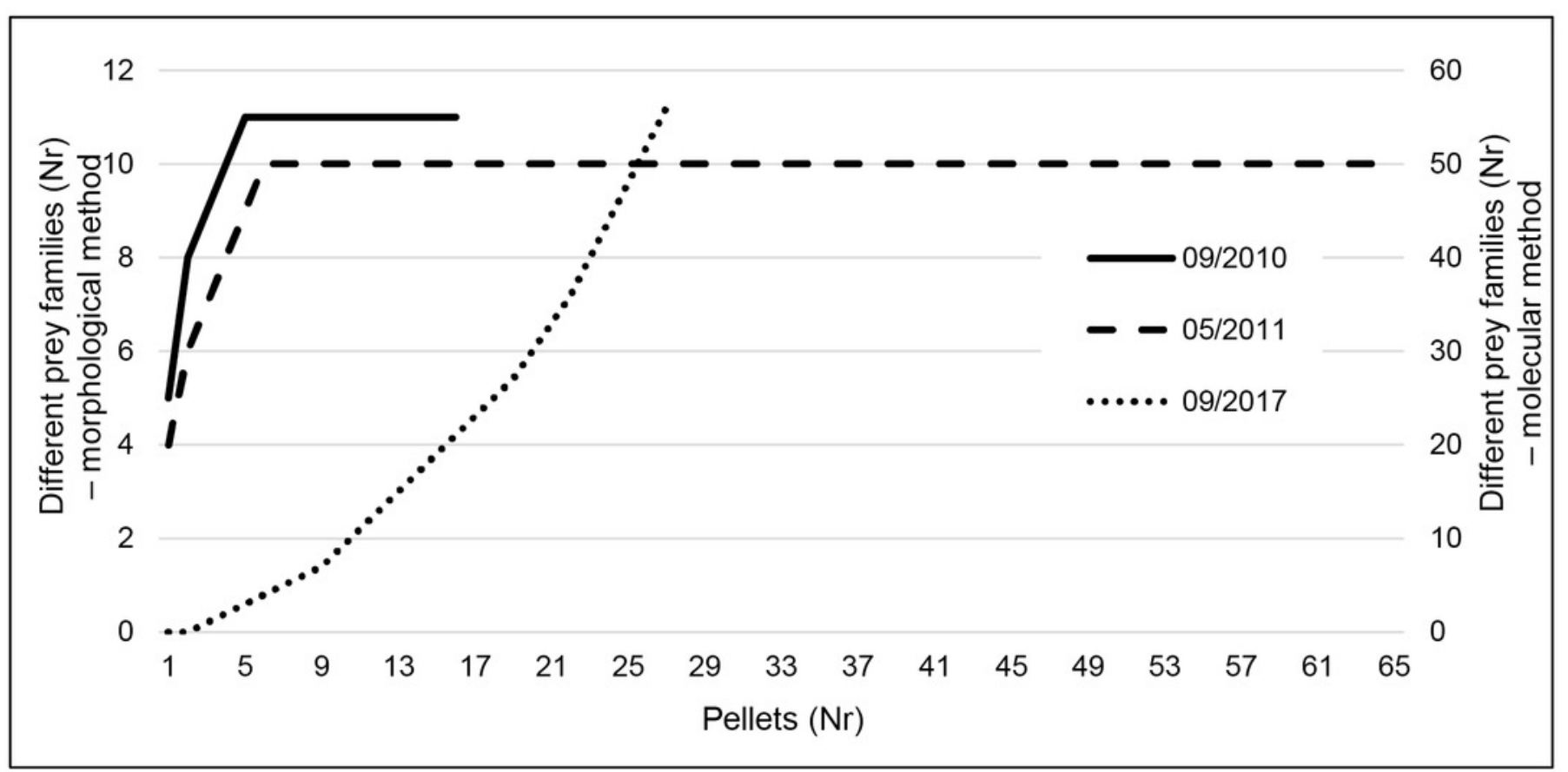

